\title{
Surface pollen and its relationships with modern vegetation and climate in the Tianshan Mountains, northwestern China
}

\author{
Haicheng $\mathrm{Wei}^{1} \cdot{\text { Yan } \mathrm{Zhao}^{2}}^{2}$
}

Received: 24 September 2014/ Accepted: 14 April 2015/Published online: 28 April 2015

(C) Springer-Verlag Berlin Heidelberg 2015

\begin{abstract}
A dataset consisting of 70 surface pollen samples from forest, alpine meadow, alpine steppe, temperate steppe, desert steppe, shrub/semi-shrub steppe and desert sites in the Tianshan Mountains, northwestern China provides an opportunity to study the relationships between surface pollen assemblages and modern vegetation and climate in this region. Redundancy analysis (RDA), the human influence index (HII) and pollen ratios were used to facilitate analysis of the pollen data. The modern pollen assemblages are primarily composed of Picea, Artemisia, Chenopodiaceae, Poaceae, Asteraceae, Nitraria and Ephedra. The results suggest that the surface pollen assemblages of different vegetation types largely represent the modern vegetation in terms of the primary taxa and dominant types. The RDA indicates that the mean annual precipitation (MAP) and the July temperature $\left(\mathrm{T}_{\text {July }}\right)$ are the major climate variables that control the modern pollen assemblages. Picea, Artemisia, Poaceae, Cyperaceae, Fabaceae, Asteraceae, Polygonaceae and Apiaceae pollen assemblages are positively correlated with MAP and negatively correlated with $\mathrm{T}_{\text {July }}$, while the pollen ratios for certain other types, such as Chenopodiaceae, Ephedra and
\end{abstract}

Communicated by M.-J. Gaillard.

Electronic supplementary material The online version of this article (doi:10.1007/s00334-015-0530-2) contains supplementary material, which is available to authorized users.

Yan Zhao

zhaoyan@igsnrr.ac.cn

1 Qinghai Institute of Salt Lakes, Chinese Academy of Sciences, Xining 810008, China

2 Institute of Geographic Sciences and Natural Resources Research, Chinese Academy of Sciences, Beijing 100101, China
Nitraria, are negatively correlated with MAP and positively correlated with $\mathrm{T}_{\text {July }}$. The arboreal/non-arboreal ratios are notably high in the forest samples, indicating a sensitive response to forest vegetation. Moreover, the Artemisia/Chenopodiaceae pollen ratios are generally correlated with the vegetation type and annual precipitation change, suggesting that these factors could be useful indicators of moisture variability in arid regions. However, it is difficult to distinguish between steppe and steppe desert based on this ratio, due partly to human disturbance. The HII is significantly correlated with certain pollen taxa, including Poaceae, Plantago, Polygonaceae and Elaeagnaceae, particularly in the alpine meadow and steppe samples. Our results have implications for interpreting the available fossil pollen data in the study region and other arid and semi-arid regions.

Keywords Modern pollen assemblages - Vegetation types $\cdot$ Climate variables $\cdot \mathrm{A} / \mathrm{C}$ ratios $\cdot$ Tianshan Mountains

\section{Introduction}

The Xinjiang region has attracted considerable attention in global change studies due to its sensitivity to environmental change (Sun et al. 1994; Thomas et al. 1996; Liu et al. 2008; Rudaya et al. 2009; Li et al. 2011a, b). Because they are one of the largest mountain systems in Xinjiang, the Tianshan Mountains have a substantial effect on climatic processes and the hydrologic cycle in Central Asia. Xinjiang is an important region for high-resolution palaeoclimatic studies because different climate systems interact and control regional climate variability in this region (Mathis et al. 2014). Fossil pollen analysis has been 
one of the most widely used approaches to reconstruct palaeovegetation and palaeoclimate records. Understanding the relationships between modern pollen assemblages and present-day vegetation is critical for interpreting fossil pollen records. Recently, Xu et al. (1996) presented modern pollen data for the southern slope of the Tianshan Mountains and calculated the $\mathrm{R}$ value of major pollen taxa. Their results show that the $\mathrm{R}$ values of Ephedra, Artemisia and Chenopodiaceae are $>1$, while Poaceae and Cyperaceae are $<1$. Similar studies have also been conducted in the central Tianshan Mountains; these studies have suggested that uplifting air in the valley plays an important role in the distribution of pollen in topsoil in the higheraltitude vegetation zones (Yang et al. 2004). Yan et al. (2004) discussed the distribution of Picea pollen in topsoil in different vegetation zones. Luo et al. (2009) presented a modern pollen-vegetation dataset based on surface soil samples in the Altay Mountains, the Junggar Basin, the eastern Tianshan Mountains, the Tarim Basin and the Kunlun Mountains. Their results indicated that Chenopodiaceae and Artemisia pollen was dominant and was well correlated with the dominant vegetation community in these regions. However, detailed information on surface pollen and its relationship with present-day vegetation remains sporadic for the Tianshan Mountains. Quantitative relationships between modern pollen and climate variables are needed for this region in order to better interpret fossil pollen data and to quantitatively reconstruct climate.

Human effects are pervasive in most ecosystems of the world. It has been estimated that more than $75 \%$ of the Earth's ice-free area has been modified by human activities; these regions can be considered as 'anthropogenic biomes' (Ellis and Ramankutty 2008). Research in recent years has shown that human impacts are not only driving current and future environmental changes, but have also played significant roles in environmental changes in the Holocene (Edwards and MacDonald 1991; Ruddiman et al. 2008; Kuneš et al. 2008). Understanding climate-human-environmental interactions at local and regional scales is the foundation for fully understanding environmental changes at a global scale; moreover, resolving our past is an essential element in predicting the future (Dearing 2006). Located in Central Asia, Xinjiang served as one of the crossroads of ancient east-west economic and cultural exchange. Agriculture activity based on oases and meadows has sustained the development of the local people for thousands of years in the Tianshan Mountains. However, little is known about the impact of human activities on the vegetation and surface pollen spectra in the Tianshan Mountains.

We present modern pollen assemblages for 70 surface topsoil samples from the Tianshan Mountains. Our objectives are as follows: (1) to obtain a better understanding of the relationships between modern pollen assemblages and both the source vegetation and regional climate in the Tianshan Mountains based on redundancy analysis (RDA) and pollen ratios and (2) to explore relationships between human effects and surface pollen assemblages in different vegetation zones within the Tianshan Mountains. This work provides a basis for the reconstruction of palaeovegetation and palaeoclimate records in this region and in other arid and semi-arid regions in surrounding area.

\section{Regional setting}

Our study area extends from $41^{\circ} 45^{\prime} \mathrm{N}$ to $44^{\circ} 55^{\prime} \mathrm{N}$ and from $81^{\circ} 00^{\prime} \mathrm{E}$ to $93^{\circ} 50^{\prime} \mathrm{E}$, with elevations ranging between 191 and $3,318 \mathrm{~m}$ (Fig. 1). The mean annual precipitation (MAP) varies from $307 \mathrm{~mm}$ in the Tianshan Mountains to less than $67 \mathrm{~mm}$ along the northern margin of the Tarim Basin. The Tianshan Mountains have a continental climate that is characterized by highly variable daily and annual temperatures. Moreover, there is a strong seasonality in the ambient air temperature, ranging from $-29^{\circ} \mathrm{C}$ in winter to $27.8{ }^{\circ} \mathrm{C}$ in summer (Hijmans et al. 2005).

Seven major vegetation zones in the Tianshan Mountains have been defined in the Vegetation Atlas of China (Hou 2001). Alpine meadows are mainly composed of Kobresia humilis, Carex, Stipa, Potentilla fragarioides, Leontopodium and Oxytropis. Mountain forest vegetation is dominated by Picea schrenkiana, Betula and other broadleaf trees. Alpine steppe regions are dominated by Poaceae, Carex, Asteraceae, Artemisia, Fabaceae, Polygonaceae, Oxytropis, P. fragarioides and Daucus carota. Both temperate steppe and desert steppe areas are dominated by Poaceae, Oxytropis, Artemisia, P. fragarioides, Taraxacum officinale, Achnatherum splendens, Leontopodium, Alhagi sparsifolia and Peganum harmala. Shrub/semi-shrub desert and desert regions primarily consist of Tamarix ramosissima, Hippophä rhamnoides,

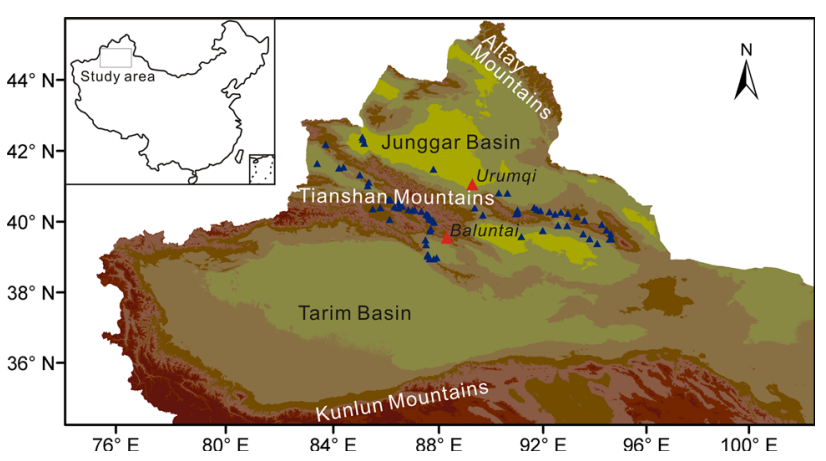

Fig. 1 Map showing the sampling site locations in the Tianshan Mountains, northwestern China. Red triangles are the locations of previous studies including Baluntai (Xu et al. 1996) and Urumqi (Yang et al. 2004) 
Haloxylon ammodendron, Ephedra, Chenopodium glaucum, Allium mongolicum and Artemisia.

Previous studies in semi-arid China indicated that due to over-grazing and over-cultivating, Leymus chinensis, Stipa sp. and A. splendens-dominated grassland is usually replaced by Cleistogenes squarrosa, Artemisia frigida, Potentilla, Stellera and $P$. harmala (Li 1997). Grazing livestock and farming are the major ways of human impact on regional vegetation in the Tianshan Mountains. Pastoral activities may exert impact on vegetation in two ways. The first is the reduction of those plants that are vulnerable to heavy livestock trampling. The second is the change of soil property and growth of nitrophilous species due to animal dung accumulated in pasture (Li et al. 2008). Some plants such as Plantago depressa, Taraxacum sp., Sonchus brachyotus, Rumex crispus, A. frigida, Tribulus terrestris and Stellera chamaejasme are common in grazed sites.

\section{Materials and methods}

\section{Field work}

We collected surface pollen samples from 70 sample sites in the aforementioned vegetation zones. The location of each plot was determined using GPS. In each of the five spruce forest vegetation sites, we surveyed one $10 \times 10 \mathrm{~m}^{2}$ quadrat for the tree layer, the quadrat size for shrubs was $5 \times 5 \mathrm{~m}^{2}$ and for grasses it was $2 \times 2 \mathrm{~m}^{2}$. The vegetation types and major plant taxa at each sampling site were recorded in the field (ESM Table 1). We also recorded the degree of human disturbance. At each site, topsoil was taken randomly from each quadrat, and was then mixed and sealed into a plastic box as one site sample.

\section{Pollen analysis}

The standard procedure outlined by Fægri and Iversen (1989) was used to chemically treat $10 \mathrm{~g}$ of each sample (dry weight). $10 \% \mathrm{HCl}$ was used to dissolve calcareous minerals, while $10 \% \mathrm{NaOH}$ was used to remove the humic components. Pollen was concentrated using a heavy liquid solution $(\mathrm{KI}+\mathrm{HI}+\mathrm{Zn})$ with a specific gravity of approximately $1.9 \mathrm{~g} / \mathrm{ml}$. Finally, cellulose and humic debris were removed by acetolysis and fine sieving used to remove clay-sized particles. Pollen taxa were identified under an optical microscope at $\times 400$ magnification. Approximately 400 terrestrial pollen grains per sample were counted and used as the pollen sum for pollen percentage calculations. Pollen diagrams were made using Tilia and Tilia-Graph software (Grimm 1991).

\section{Numerical analysis}

There are only seven local meteorological stations available in our study region; modern site-specific climate data were extracted from the WorldClim dataset with a spatial resolution of 30 arc-seconds (Hijmans et al. 2005). Two important climate parameters, i.e., the MAP and the July mean temperature $\left(\mathrm{T}_{\text {July }}\right)$, were used in this study. A correction to the values was made according to calculated elevation-based local lapse rates using the difference between the altitudes of the climate stations and the sampling sites.

Ordination techniques have been widely used for analyzing relationships among pollen taxa, vegetation data and environmental variables (Schofield et al. 2007; Zhao et al. 2007; Zhao and Herzschuh 2009; Zhang et al. 2010). A detrended correspondence analysis (DCA) was initially performed to estimate the underlying linearity of the data. The DCA results show that the gradient lengths of the first four axes are less than 2.02 SDs, suggesting that the underlying responses are linear. Therefore, we chose the RDA technique to explore site-to-site similarities and the primary taxonomic variation patterns among the samples. The RDA was processed using the Canoco software package (Ter Braak and Šmilauer 2002). In this study, only modern pollen assemblages in which the pollen percentage of that taxon exceeded $2 \%$ in at least one sample were used in the numerical analysis. MAP, $\mathrm{T}_{\text {July }}$ and human influence index (HII) were selected as environmental variables to determine the effects of different environmental factors on the surface pollen distribution.

The Artemisia/Chenopodiaceae ratio (A/C ratio) is often used as a proxy for moisture. Previous studies in the drylands of the Middle East (El-Moslimany 1990) have demonstrated that Chenopodiaceae are indicators of saline or non-saline desert vegetation, whereas Artemisia pollen generally increases with increasing MAP. Thus, the ratio of these two taxa has been used as an index for moisture regimes (Wang et al. 1996; Liu et al. 1999; Li et al. 2005; Zhao et al. 2009, 2012). In our study, the $\mathrm{A} / \mathrm{C}$ ratio was calculated to understand the response of this ratio to changes in MAP within vegetation zones in the study area and to determine if the $\mathrm{A} / \mathrm{C}$ ratio can be used for semiquantitative palaeoclimate reconstructions.

Surface pollen studies are critical for quantitative reconstruction of past temperature and precipitation using the pollen record. However, human influence on vegetation is a potential confounding factor in pollen-based quantitative climate reconstructions (Birks and Seppä 2004). Therefore, in this study we employed HII values to detect the impact of human activities on surface pollen. HII values for individual pollen sampling sites were derived from the global HII dataset with a spatial resolution of $1 \mathrm{~km}^{2}$ (Sanderson 
et al. 2002). This dataset has been produced by synthesizing several indices that reflect the intensity of human effects, such as the human population density, infrastructure (including built-up areas and land use), and accessibility (such as coastlines, roads, railways and navigable rivers). The HII values range from a minimum of 0 to a maximum of 64 (Sanderson et al. 2002; WCS/CIESIN 2005).

\section{Results}

\section{Pollen assemblages}

Forty-seven pollen taxa were identified from the 70 surface samples (Fig. 2). Arboreal pollen assemblages are dominated by Picea. The total tree pollen percentages in the mountain forest samples are primarily $>50 \%$, while the tree pollen percentages are $<25 \%$ in the adjacent alpine meadow and steppe zone samples, and $<10 \%$ is common for the samples collected in the other vegetation zones. The shrub and herb pollen percentages are primarily $>85 \%$ in the non-arboreal vegetation samples and are dominated by Artemisia, Chenopodiaceae, Cyperaceae, Poaceae and Ephedra; some Asteraceae, Fabaceae, Rosaceae, Ranunculaceae, Caryophyllaceae, Nitraria and Tamaricaceae are also present.

The abundance of each pollen taxon varies according to the different vegetation types. At the mountain forest sampling sites, the pollen assemblages are dominated by Picea (50.8-82.6\%; median $71.3 \%$ ). In the alpine meadow samples, the most abundant pollen type is from Cyperaceae (up to $87 \%$, median $45 \%$ ), while other common pollen types include Artemisia, Chenopodiaceae, Poaceae, Caryophyllaceae and Thalictrum. The pollen assemblages in the alpine steppe samples are dominated by Artemisia (up to $54.1 \%$; median $23.8 \%$ ), Chenopodiaceae (up to $27.3 \%$; median $15.3 \%$ ), Poaceae (median $11.5 \%$ ) and Cyperaceae (median $9.2 \%$ ), with some Picea $(4.3 \%$ ), Asteraceae (3.6\%) and Ephedra (3.1\%). The temperate steppe samples are dominated by Chenopodiaceae (up to $84.4 \%$, median $31 \%$ ), Artemisia (up to $57.1 \%$; median $16.8 \%$ ), Poaceae (median $6.7 \%$ ), and Asteraceae (median $2.5 \%)$. The steppe desert samples exhibit abundant Chenopodiaceae (mean $41.6 \%$ ) and Artemisia (mean $33.4 \%$ ). In the shrub/semi-shrub desert and desert samples, the mean percentage of Artemisia decreases to $14.7 \%$, whereas the percentage of Chenopodiaceae increases to $52.1 \%$. Moreover, Ephedra (up to $46.5 \%$ at sites with Ephedra przewalskii communities), Tamaricaceae (up to $18.5 \%$ at sites with T. elongata communities), and Zygophyllaceae (up to $39.7 \%$ at sites with $P$. harmala communities) are found in these regions.
Fig. 2 Modern pollen assemblages based on surface samples obtained from the Tianshan Mountains, northwestern China

Nitraria, Poaceae and Asteraceae are present in low abundances, while Picea is frequently present in these regions (mean $3.8 \%$ ).

The AP/NAP ratio is 2.8 in the mountain forest samples, 0.04 in the alpine meadow samples, 0.09 in the alpine steppe samples, 0.07 in the temperate steppe samples, and 0.06 in the steppe desert, shrub/semi-shrub desert and desert samples. The mean $\mathrm{A} / \mathrm{C}$ ratio is 1.2 in the mountain forest and alpine meadow samples, while the mean is 1.7 in the alpine steppe samples, 1.0 in the temperate steppe samples, 0.8 in the steppe desert samples, 0.6 in the shrub/ semi-shrub desert samples and 0.2 in the desert samples.

\section{Numerical analysis results}

The RDA ordination for surface pollen percentage of the 31 taxa with environmental factors (Fig. 3) shows that all climate variables are statistically significant in relation to the variance in pollen data $(\mathrm{P}<0.03)$, with MAP capturing the largest proportion (ESM Table 2). The first axis (eigenvalue $=0.225$ ) explains $76.2 \%$ of the variation in the dataset. The correlation between the first axis and the species-environmental variables is 0.742 . The second axis (eigenvalue $=0.04)$ explains $18.28 \%$ of the variation, the correlation between the second axis and the species-environmental variables being 0.576. MAP and $\mathrm{T}_{\text {July }}$ are the primary factors that control the variations found in the surface pollen data for the Tianshan Mountains (Fig. 3a). HII exhibits smaller correlations with the two axes (i.e., -0.41 and 0.62), implying that the effects of changes in the HII are less significant than changes in MAP and $\mathrm{T}_{\text {July }}$ on the surface pollen distribution. However, HII is significantly correlated with some taxa, including Poaceae, Plantago, Polygonaceae and Elaeagnaceae. Some alpine meadow and alpine steppe samples are also correlated with the HII (Fig. 3). Therefore, human influences may partially affect surface pollen assemblages in the alpine meadow and alpine steppe regions of the study area (Fig. 3). Human influences are also reflected by changes in Poaceae, Plantago, Polygonaceae and Elaeagnaceae pollen due to the good correlation between these pollen taxa and HII values.

The RDA results based on surface pollen samples indicate that the first axis primarily grouped most samples into two categories, i.e., alpine meadows/steppes and steppe deserts/deserts. In the sample-environment biplot (Fig. 3a), the lengths of the arrows for the climatic variables approximately correspond to their relative importance in the pollen variance, while the orientation shows their approximate correlations to the ordination axes and 


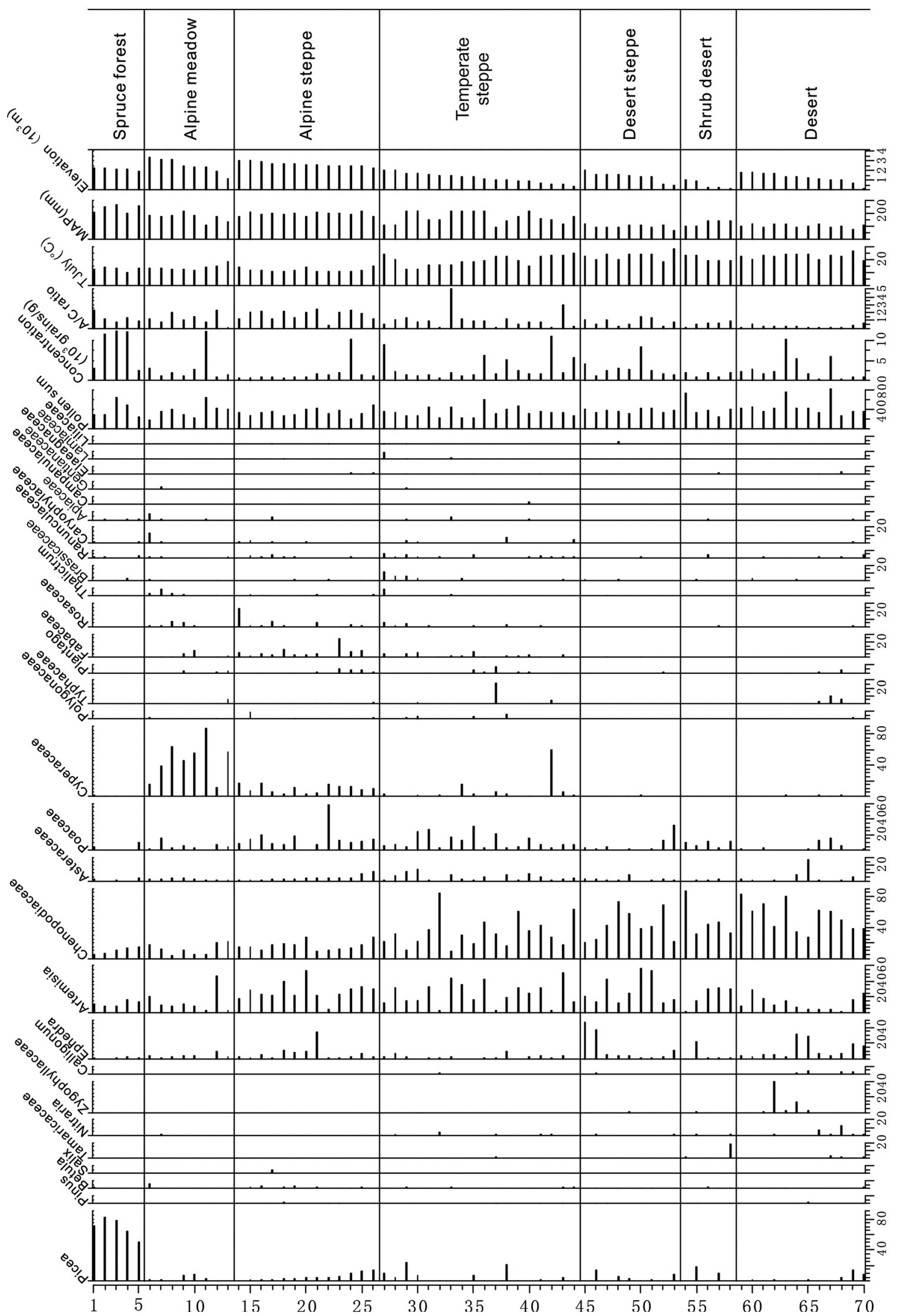



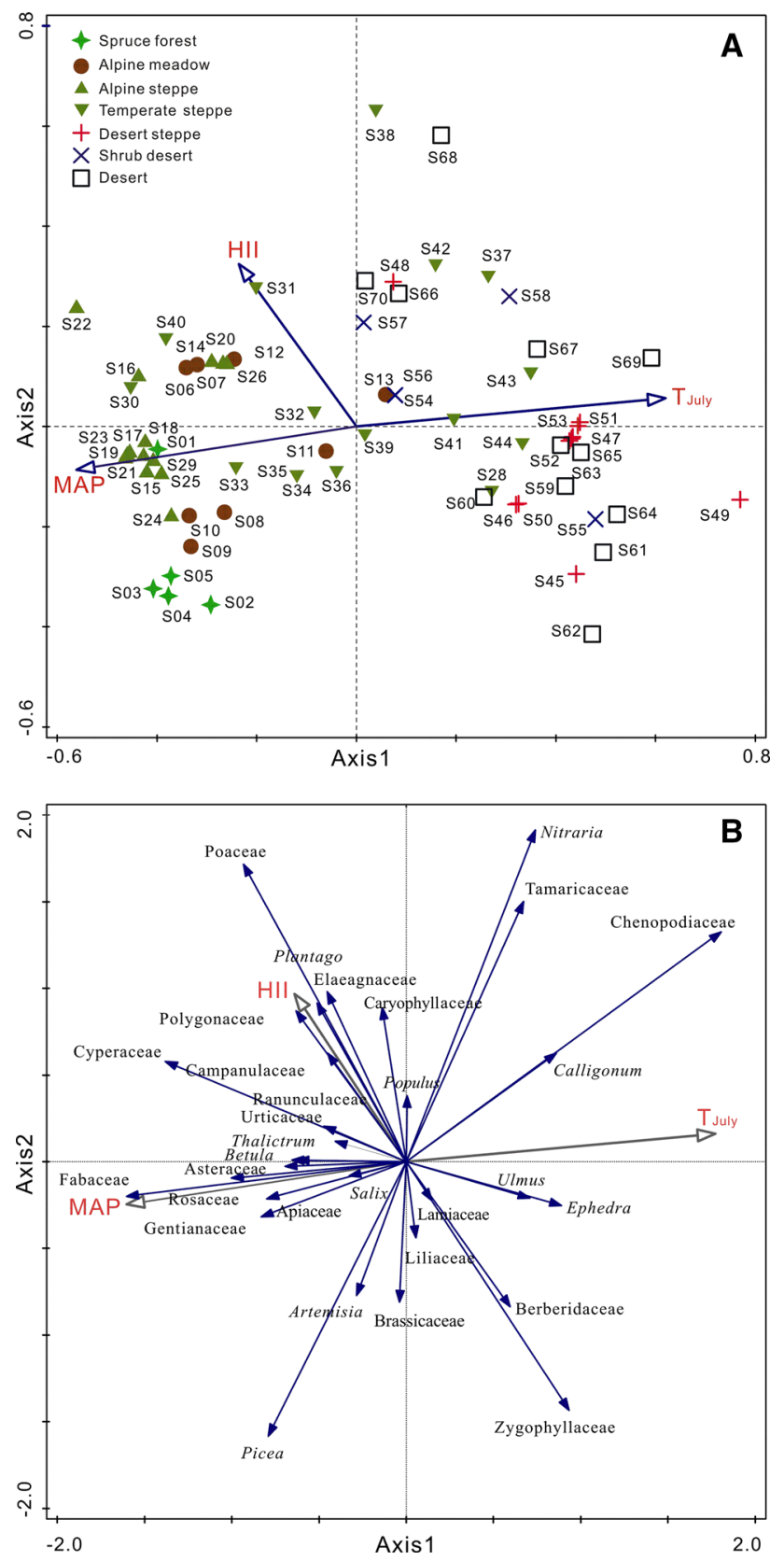

Fig. 3 Redundancy analysis (RDA) results for the surface pollen data from the Tianshan Mountains, northwestern China. a Biplot of the RDA results based on the surface pollen samples; $\mathbf{b}$ biplot of the RDA results based on the surface pollen taxa. Environmental variables including HII are plotted in the biplots

the climate variables. MAP is closely related to the negative first axis, while $\mathrm{T}_{\text {July }}$ is positioned to the right of the first axis. Moreover, the pollen sample sites with high MAP are generally positioned to the left of the first axis in the RDA biplot (i.e., sites in spruce forests, alpine meadows, alpine steppes and most temperate steppe regions), while the pollen sample sites with low MAP and high $\mathrm{T}_{\text {July }}$ are located to the right of the first axis (i.e., sites in steppe deserts, shrub/semi-shrub deserts and deserts).
The taxa biplot of the RDA results (Fig. 3b) indicates that the samples from various vegetation types are dominated by different taxa. The pollen assemblages from the mountain forest samples are dominated by Picea, while the pollen assemblages from the alpine meadow samples are dominated by Cyperaceae. The pollen assemblages from the alpine steppe and temperate steppe samples are dominated by Artemisia, Asteraceae, Fabaceae, Rosaceae, Ranunculaceae, Caryophyllaceae and Polygonaceae, while the pollen assemblages from the shrub/semi-shrub desert, steppe desert and desert samples are dominated by Chenopodiaceae, Ephedra, Calligonum, Tamaricaceae, Zygophyllaceae and Nitraria.

\section{Discussion}

\section{Pollen representation of modern vegetation}

Our investigation reveals that the main modern vegetation zones can be distinguished by their modern pollen assemblages in the RDA scatter plots. Picea is the dominant taxon in the mountain forest samples; Cyperaceae are the most important taxa in the alpine meadow samples. Artemisia, Chenopodiaceae, Poaceae and Cyperaceae are the dominant taxa in the alpine steppe samples, while Artemisia, Chenopodiaceae, and Poaceae are the dominant taxa in the temperate steppe and steppe desert samples. In the shrub/semi-shrub desert and desert samples, Ephedra and Chenopodiaceae are the dominant taxa in the pollen assemblages. These results suggest that the surface pollen assemblages generally represent the modern vegetation composition and the dominant taxa; therefore, fossil pollen data can be applied to the qualitative vegetation reconstruction in the region of the Tianshan Mountains.

Picea pollen occurs in most of the collected samples even though no spruce trees are located near the sampling sites. This finding can be attributed to the long-distance dispersal capacity of Picea pollen, suggesting an overrepresentation of Picea pollen. However, the percentage never exceeds $20 \%$ except in the spruce forest samples, implying that $>20 \%$ of Picea can represent the local presence of spruce trees in the study region. This result agrees with previous studies in arid regions of China (Yan et al. 2004; Luo et al. 2009).

Pollen from Artemisia and Chenopodiaceae is present with very high percentages in the surface pollen samples and is clearly over-represented. These results agree with the findings of many former studies of surface pollen samples in arid regions of China (Xu et al. 1996; van Campo et al. 1996; Carrion 2002; Herzschuh et al. 2003, 2006; Yang et al. 2004; Luo et al. 2010; Zhao and Herzschuh 2009). 
Poaceae exhibit low percentages in all of the samples even though Poaceae plants are abundant in the steppe vegetation zones (mean $8.4 \%$ ), suggesting that its pollen is under-represented. Similar conclusions have been drawn in a few studies in the steppe and desert regions of northern China (Li et al. 2005; Wei et al. 2011).

Ephedra pollen is present at nearly all of the sampling sites with percentages between 0 and $46.5 \%$, suggesting that Ephedra pollen has a high dispersal capacity. The abundance of Ephedra pollen is high at the sites containing modern plants and low at the sites without Ephedra plants. Nitraria pollen is primarily found at the shrub/semi-shrub desert and desert sampling sites, suggesting that Nitraria pollen is strongly correlated with its source plants. Our results are consistent with previously published findings from northwestern China and the northeastern Tibetan Plateau (Herzschuh et al. 2003; Wei et al. 2011).

\section{Relationships between pollen assemblages and climate variables}

The RDA results show that the modern pollen assemblages in the study region are primarily controlled by MAP; however, the July temperature also has a significant effect in controlling the vegetation distribution. This result agrees with previously published findings based on modern pollen studies for the Tibetan Plateau and northwestern China (Shen et al. 2006; Zhao and Herzschuh 2009; Li et al. 2011a, b; Wei et al. 2011). The alpine meadow samples in which Cyperaceae are the dominant pollen taxa indicate relatively high MAP and low $\mathrm{T}_{\text {July }}$. In contrast, the shrub/ semi-shrub desert and desert samples in which Chenopodiaceae, Ephedra, Nitraria and Tamaricaceae are the dominant pollen taxa indicate relatively low MAP and high $\mathrm{T}_{\text {July. }}$. The spruce forest samples in which Picea is the dominant pollen taxon exhibit relatively high MAP and moderate $\mathrm{T}_{\mathrm{July}}$, while the steppe samples in which Artemisia, Asteraceae, Fabaceae, and Rosaceae are the dominant pollen taxa are found at relatively moderate MAP and temperature values.

\section{Pollen assemblages and HII}

The RDA ordination reveals that the HII is significantly correlated with Poaceae, Plantago and Polygonaceae pollen. Poaceae pollen is typically high in farmland and enclosed regions and low in degraded grasslands. Liu et al. (2006) collected and analyzed surface pollen samples along moisture and human impact gradients in the steppe zone of East Asia to understand the relationships between climate, human activity and surface pollen assemblages. Their results indicated that severe human disturbance leads to increased Chenopodiaceae percentages (Zhang et al. 2010).
Research has also shown that the under-representation of Poaceae in surface pollen samples in steppe regions could be the result of human-induced disturbances, such as overcultivation and overgrazing (Ma et al. 2008). In this study, the HII is correlated with several pollen taxa, including Poaceae, Plantago, Polygonaceae and Elaeagnaceae, particularly in the alpine meadow and steppe samples. Some pollen taxa such as Chenopodiaceae, Plantago and Taraxacum are common in the pollen assemblages from the oasis. It suggests that human influences, including overcultivation and overgrazing, could affect the surface pollen assemblages in the alpine meadow and steppe vegetation zones in the Tianshan Mountains.

\section{Pollen ratios and their climatic indication}

In our surface pollen assemblages, AP/NAP is high in forests and low in the other vegetation zones (all less than 0.1). Previous pollen studies of lake-surface sediments have indicated that the AP/NAP ratio is typically highest in forest areas (Herzschuh 2007). Therefore, the AP/NAP ratio is a sensitive proxy for forest vegetation in the study area; however, the ratio does not decrease when the vegetation type changes from alpine meadow, steppe and shrub desert to desert.

The mean $\mathrm{A} / \mathrm{C}$ pollen ratios decrease from the alpine steppe samples to the temperate steppe and desert samples (Fig. 4). Although the mean $\mathrm{A} / \mathrm{C}$ pollen ratios of the mountain forest and alpine meadow samples exceed 1, they are not the highest of all the vegetation types, which is analogous to the findings of previous work in arid and semi-arid regions of China (Zhao et al. 2012), while the $\mathrm{A} / \mathrm{C}$ ratios in most arid and semi-arid regions of China are $<0.5$ for deserts, $0.5-1.2$ for steppe deserts, and $>1$ for

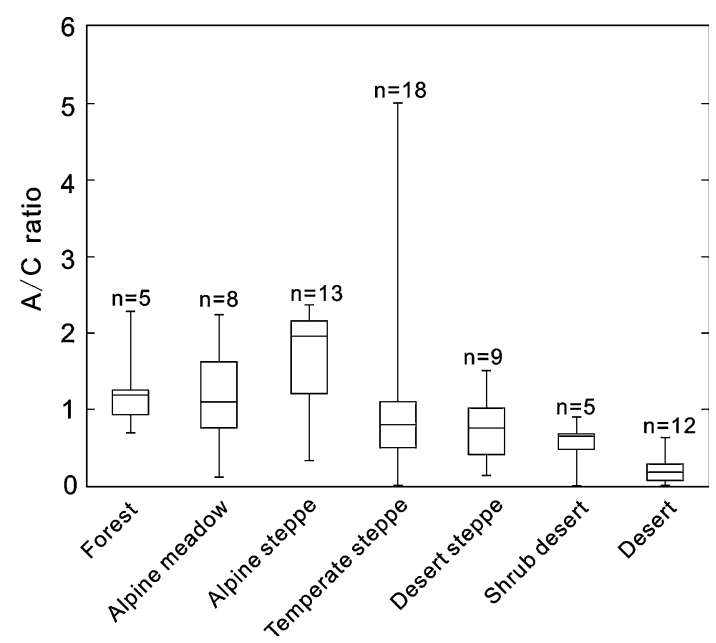

Fig. 4 Median and boxplots of the A/C ratios from the surface samples for different vegetation types in the Tianshan Mountains, northwestern China. The medians (central lines), inner quantile ranges (boxes), and 25th and 75th percentiles are shown 


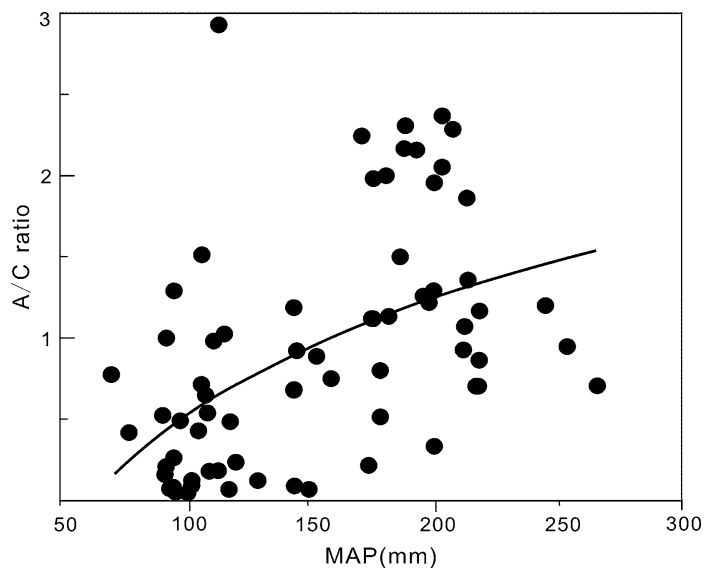

Fig. 5 Scatter diagrams of the mean annual precipitation versus the A/C ratios from the Tianshan Mountains, northwestern China

typical steppes (Yan 1991; Liu et al. 1999; Herzschuh et al. 2003; Luo et al. 2010; Li et al. 2011a, b). Cour et al. (1999) indicated that saline deserts, montane deserts and montane steppes are represented by A/C ratios of $<1,1-2$ and $>2$, respectively on the Qinghai-Tibet Plateau. A surface pollen study on the northeastern Qinghai-Tibet Plateau also showed that $\mathrm{A} / \mathrm{C}$ ratios are typically $>2$ in steppe areas, $<0.8$ in desert areas, and range from 0.5 to 1.2 in desertsteppe areas (Zhao et al. 2009; Wei et al. 2011). Our results indicate that precipitation is the most important factor that affects the $\mathrm{A} / \mathrm{C}$ ratio; therefore, the ratio can be used as an indicator of precipitation in the Tianshan Mountains (Fig. 5). Abundant Artemisia and Chenopodiaceae in the study region also permit the use of the $\mathrm{A} / \mathrm{C}$ ratio for reconstructing palaeovegetation records. However, A/C varies among the steppe sample sites, i.e., some temperate steppe sample sites exhibit low A/C ratios, which makes it challenging to distinguish between steppe and steppe desert regions. This finding is probably due to the cross-distribution of vegetation in temperate steppes and deserts within the study area. Overgrazing in steppe areas has caused grassland degradation and can account for the high Chenopodiaceae pollen concentrations found at several sampling sites (Liu et al. 2006). Therefore, caution must be taken when using $\mathrm{A} / \mathrm{C}$ ratios to distinguish the steppe from desert steppe in palaeovegetation reconstruction.

\section{Conclusions}

The surface pollen assemblages from the Tianshan Mountains are representative of the major vegetation types. Based on RDA, the pollen assemblages are primarily controlled by MAP and $\mathrm{T}_{\text {July. }}$. The HII is significantly correlated with several pollen taxa, including Poaceae, Plantago, Polygonaceae and Elaeagnaceae, particularly in alpine meadows and steppes. Human influences, including over-cultivation and overgrazing, can affect the surface pollen assemblages. The AP/NAP ratio is very high in forest regions and is found to be sensitive to forest vegetation in the study area. The $\mathrm{A} / \mathrm{C}$ ratio decreases in the following order in the study area: alpine steppes, steppes, desert steppes, shrub deserts and deserts, with the decrease in precipitation, which suggests that this ratio can be used as an indicator of both vegetation type and moisture. Our results have implications for interpreting fossil pollen records and reconstructing moisture changes in the Tianshan Mountains and other arid and semi-arid regions.

Acknowledgments We thank Furong Li, Jinhui Sun and Wenwei Zhao for collecting the samples and investigating the vegetation. This research was supported by the 100 Talents Program of the Chinese Academy of Sciences and the National Natural Science Foundation of China (Grants \#41125006 and 41330105). We are grateful to the editor and two anonymous reviewers for their helpful comments and suggestions to improve the manuscript.

\section{References}

Birks HJB, Seppä H (2004) Pollen-based reconstructions of lateQuaternary climate in Europe-progress, problems, and pitfalls. Acta Palaeobot 44:317-334

Carrion JS (2002) A taphonomic study of modern pollen assemblages from dung and surface sediments in arid environments of Spain. Rev Palaeobot Palynol 120:217-232

Cour P, Zheng Z, Duzer D, Calleja M, Yao Z (1999) Vegetation and climatic significance of modern pollen rain in northwestern Tibet. Rev Palaeobot Palynol 104:183-204

Dearing JA (2006) Climate-human-environment interactions: resolving our past. Clim Past 2:187-203

Edwards KJ, MacDonald GM (1991) Holocene palynology II: human influence and vegetation change. Prog Phys Geogr 15:364-391

Ellis EC, Ramankutty N (2008) Putting people in the map: anthropogenic biomes of the world. Front Ecol Environ 6:439-447

El-Moslimany AP (1990) The ecological significance of common nonarboreal pollen: examples from dryland of the Middle East. Rev Palaeobot Palynol 64:343-350

Fægri K, Iversen J (1989) In: Fægri K, Kaland PE, Krzywinski K (eds) Textbook of pollen analysis, 4th edn. Wiley, Chichester

Grimm EC (1991) Tilia-graph program. Illinois State Museum, Springfield

Herzschuh U (2007) Reliability of pollen ratios for environmental reconstructions on the Tibetan Plateau. J Biogeogr $34: 1,265-1,273$

Herzschuh U, Kürschner H, Ma YZ (2003) The surface pollen and relative pollen production of the desert vegetation of the Alashan Plateau, western Inner Mongolia. Chin Sci Bull 48:1,488-1,493

Herzschuh U, Kürschner H, Battarbee R, Holmes J (2006) Desert plant production and a 160-year record of vegetation and climate change on the Alashan Plateau, NW China. Veget Hist Archaeobot 15:181-190

Hijmans RJ, Cameron SE, Parra JL, Jones PG, Jarvis AJ (2005) Very high resolution interpolated climate surfaces for global land areas. Int J Climatol 25:1,965-1,978 
Hou H (2001) Vegetation atlas of China. Science Press, Beijing

Kuneš P, Pokorný P, Šída P (2008) Detection of the impact of early Holocene hunter-gatherers on vegetation in the Czech Republic, using multivariate analysis of pollen data. Veget Hist Archaeobot 17:269-287

Li B (1997) Grassland degradation and measurements in northern China. Sci Agric Sin 30:1-9 (in Chinese with English abstract)

Li YC, Xu QH, Zhao YK, Yang XL, Xiao JL, Chen H, Lu XM (2005) Pollen indication to source plants in the eastern desert of China. Chin Sci Bull 50:1,632-1,641

Li YY, Zhou LP, Cui HT (2008) Pollen indicators of human activity. Chin Sci Bull 53:1,281-1,293

Li XQ, Zhao KL, John D, Zhou XY (2011a) Moisture dynamics in central Asia for the last 15 kyr: new evidence from Yili Valley, Xinjiang, NW China. Quat Sci Rev 30:3,457-3,466

Li YC, Bunting MJ, Xu QH, Jiang SX, Ding W, Hun LY (2011b) Pollen-vegetation-climate relationships in some desert and desertsteppe communities in Northern China. Holocene 21:997-1,010

Liu HY, Cui HT, Pott R, Speier M (1999) The surface pollen of the woodland-steppe ecotone in southeastern Inner Mongolia, China. Rev Palaeobot Palynol 105:237-250

Liu HY, Wang Y, Tian YH, Zhu JL, Wang HL (2006) Climatic and anthropogenic control of surface pollen assemblages in East Asian steppes. Rev Palaeobot Palynol 138:281-289

Liu XQ, Herzschuh U, Shen J, Jiang QF, Xiao XY (2008) Holocene environmental and climatic changes inferred from Wulungu Lake in northern Xinjiang, China. Quat Res 70:412-425

Luo CX, Zheng Z, Tarasov P, Pan AD, Huang KY, Beaudouin C, An FZ (2009) Characteristics of the modern pollen distribution and their relationship to vegetation in the Xinjiang region, northwestern China. Rev Palaeobot Palynol 153:282-295

Luo CX, Zheng Z, Tarasov P, Nakagawa T, Pan AD, Xu QH, Lu HY, Huang KY (2010) A potential of pollen-based climate reconstruction using a modern pollen-climate dataset from arid northern and western China. Rev Palaeobot Palynol 160:111-125

Ma YZ, Liu KB, Feng ZD, Sang YL, Wang W, Sun AZ (2008) A survey of modern pollen and vegetation along a south-north transect in Mongolia. J Biogeogr 35:1,512-1,532

Mathis M, Sorrel P, Klotz S, Huang XT, Oberhänsli H (2014) Regional vegetation patterns at lake Son Kul reveal Holocene climatic variability in central Tien Shan (Kyrgyzstan, Central Asia). Quat Sci Rev 89:169-185

Rudaya N, Tarasov P, Dorofeyuk N, Solovieva N, Kalugin I, Andreev A, Daryin A, Diekmann B, Riedel F, Tserendash N, Wagner M (2009) Holocene environments and climate in the Mongolian Altai reconstructed from the Hoton-Nur pollen and diatom records: a step towards better understanding climate dynamics in Central Asia. Quat Sci Rev 28:540-554

Ruddiman WF, Guo ZT, Zhou X, Wu HB, Yu YY (2008) Early rice farming and anomalous methane trends. Quat Sci Rev 27:1,291-1,295

Sanderson EW, Jaiteh M, Levy MA, Redford KH, Wannebo AV, Woolmer G (2002) The human footprint and the last of the wild. Bioscience 52:891-904

Schofield JE, Edwards KJ, McMullen AJ (2007) Modern pollenvegetation relationships in subarctic southern Greenland and the interpretation of fossil pollen data from the Norse landnám. J Biogeogr 34:473-488

Shen CM, Liu KB, Tang LY, Overpeck JT (2006) Quantitative relationships between modern pollen rain and climate in the Tibetan Plateau. Rev Palaeobot Palynol 140:61-77
Sun XJ, Du NQ, Weng CY, Lin RF, Wei KQ (1994) Paleovegetation and paleoenvironment of Manas Lake, Xinjiang, northwestern China during the last 14,000 years. Quat Sci 3:239-248 (in Chinese with English abstract)

Ter Braak CJF, Šmilauer P (2002) CANOCO reference manual and CanoDraw for Windows user's guide: software for canonical community ordination (version 4.5). Microcomputer Power, Ithaca

Thomas ER, Francoise G, Lin RF, Jean-Charles F, Wei KQ, Philippe B, Elisabeth G, Fredric M, Piotr T, Wang ZX, Cheng ZY (1996) A late pleistocene-Holocene lacustrine record from Lake Manas, Zunggar (northern Xinjiang, western China). Palaeogeogr Palaeoclimatol Palaeoecol 120:105-121

van Campo E, Cour P, Huang S (1996) Holocene environmental changes in Bangong Co basin (West Tibet). Part 2: the pollen record. Palaeogeogr Palaeoclimatol Palaeoecol 120:49-63

Wang BY, Song CQ, Sun XJ (1996) Study on surface pollen in middle Inner Mongolia, China. Acta Bot Sin 38:902-909 (in Chinese with English abstract)

WCS/CIESIN (2005) Last of the wild data version 2: global human influence index (HII). Wildlife Conservation Society (WCS) and Center for International Earth Science Information Network (CIESIN). http://sedac.ciesin.columbia.edu/data/set/wildareasv2-human-influence-index-geographic

Wei HC, Ma HZ, Zheng Z, Pan AD, Huang KY (2011) Modern pollen assemblages of surface samples and their relationships to vegetation and climate in the northeastern Qinghai-Tibetan Plateau, China. Rev Palaeobot Palynol 163:237-246

Xu Y, Yan S, Jia B, Yang Y (1996) Numerical relationship between the surface spore pollen and surrounding vegetation on the southern slope of Tianshan Mountain. Arid Land Geogr 19:24-30 (in Chinese)

Yan S (1991) The characteristics of Quaternary sporo-pollen assemblage and the vegetation succession in Xinjiang. Arid Land Geogr 14:1-9 (in Chinese)

Yan S, Kong ZC, Yang ZJ, Zhang Y, Ni J (2004) Seeking relationship between vegetation and Picea pollen in surface soils of Xinjiang, northwestern China. Acta Ecol Sin 24:2,017-2,023 (in Chinese)

Yang ZJ, Kong ZC, Yan S, Ni J, Ma KP, Xu QH (2004) Pollen distribution in topsoil along the Daxigou Valley in the headwaters of the Urumqi River, the central Tianshan Mountains. Arid Land Geogr 27:543-547 (in Chinese)

Zhang Y, Kong ZC, Wang GH, Ni J (2010) Anthropogenic and climatic impacts on surface pollen assemblages along a precipitation gradient in north-eastern China. Glob Ecol Biogeogr 19:621-631

Zhao Y, Herzschuh U (2009) Modern pollen representation of source vegetation in the Qaidam Basin and the surrounding mountains, north-eastern Tibetan Plateau. Veget Hist Archaeobot $18: 245-260$

Zhao Y, Yu ZC, Chen FH, Ito E, Zhao C (2007) Holocene vegetation and climate history at Hurleg Lake in the Qaidam Basin, northwest China. Rev Palaeobot Palynol 145:275-288

Zhao Y, Yu ZC, Chen FH (2009) Spatial and temporal patterns of Holocene vegetation and climate changes in arid and semi-arid China. Quat Int 194:6-18

Zhao Y, Liu HY, Li FR, Huang XZ, Sun JH, Zhao WW, Herzschuh U, Tang Y (2012) Application and limitation of Artemisial Chenopodiaceae pollen ratio in arid and semi-arid China. Holocene 22:1,385-1,392 